\title{
ENGINEERING FACTORS AFFECTING THE OUTLET WATER TEMPERATURE OF SOLAR WATER HEATER
}

\author{
N.M El-Ashmawy ${ }^{*} \quad$ M.R.A Darwesh ${ }^{* *} \quad$ G.D.M. Yousef ${ }^{* * *}$
}

\section{ABSTRACT}

The application of solar energy as a clean renewable source of energy in agricultural purposes has the major interest worldwide especially in countries with a high solar insolation. The aim of this study was to investigate the effect of some factors ; solar radiation incident, water flow rate, water inlet temperature, ambient air temperature and absorber plate temperature on outlet temperatur of the operating fluid. A solar heating system icludes a solar collector has an area of $2 \mathrm{~m}^{2}$, an insulated storage tank, a heat exchanger, a fluid distribution system and a control system was constructed and installed in Densosher village, El-Mehalla ElKobra, Gharbia Governorate at a latitude angle of $30.9 N^{\circ}$. The collected data for this research restricted between 15 August and 25 September 2010. The statistical analysis, forward stepwise regression, revealed that the water inlet and the absorber plate temperatures had the major effect on the water outlet temperature as compared with the other parameters.

\section{INTRODUCTION}

lat plate solar collectors used in many applications; heating,
cooling, strelization root media. The solar energy absorbed by the
plate is transferred to the operating fluid in the collector tubes. To optimize the absorption of the solar radiation which depends on the temperature level required for the specific application and the climatic conditions of the site of installation.

One of the factors is the outlet temperature from solar collector which determined the application what used. The factors which affect the outlet temperature can be classified into two categories; control factors and the environmental factors.

\footnotetext{
* Researcher, Agric. Eng. Res. Inst., Agric. Research Center, Giza, Egypt **Lecturer, Agric. Eng. Dep., Fac. Of Agric., Tanta Univ., Tanta, Egypt ***Researcher, Horti Res. Inst., Agric. Research Center, Giza, Egypt
} 
The control factors are the parameters which can be specified freely by a designer such as: inlet fluid temperature and difference between inlet and outlet fluid temperature. The environmental factors are the parameters that are not under a designer's control such as: solar radiation and ambient air temperature. Considerable effort has been expended over the years to improve and increase thermal efficiency and the output temperatures of flat plate solar collectors. This effort has been made with several goals in mind. One is to store heat more efficiently for use during nights and cloudy days when stored as latent heat, a high temperature contains more calories per gram of matter. A second goal is to increase the temperature so that other tasks than simply providing hot water are possible, (Meinel and Meinel, 1979).

Abdellatif (1985) employed a solar panel for heating water at $51^{\circ} \mathrm{N}$ latitude angle (Wye, England) in order to utilize the stored solar energy in the storage tank for solution heating in Nutrient Film Technique lettuce production inside a greenhouse. The results revealed that, the solar energy system provided $29.3 \%, 58.7 \%$ and $72.8 \%$ for winter, spring and summer crops, respectively. Most solar energy systems are capital intensive; therefore care has to be taken with system design to achieve the optimum configuration. General solar system design procedures have often been resulted from experience gained in the construction and operation of several systems. However, this has normally taken a number of years to develop an acceptable method. The solar energy for agricultural applications is strongly dependent upon the development of solar energy systems that have optimum performance, good reliability, and economic characteristics.Any blackened flat plate exposed to strong solar radiation will absorb energy and its temperature will rise above that of its surroundings. When the fluid is circulated through suitable paths formed in the plate or allowed to run over the surface of the plate; some of the absorbed energy will be transferred to the fluid as a useful heat gain. The rest of the absorbed energy will be dissipated to the surroundings through radiation, convection, and conduction heat transfers. The thermal performance of solar water heaters is influenced by the mass flow rate of water which is circulated through the solar system (George et al., 1980; Jesch and Braun, 1984; and Fanney and 
Klein, 1988).Operating and environmental parameters affecting the thermal performance of flat plate solar collectors were also investigated by Abdellatif et al. (1990). The specific conclusions they obtained were 1) As the water volume inside the solar collector per unit area of absorber black plate increased, the heat transfer rate was increased and rate of absorbed thermal energy converted into useful heat gain to storage was thus increased. 2) As the length of the water column passing through the solar collector reduced, the operating temperature was reduced making the heat transfer between the water and absorber plate more efficient. 3) As the solar collector situated inside the polyethylene shade was sheltered from the effect of wind, the thermal performance of the solar system was more efficient than the other system located outside.Li and Wang (2002) proposed a new flat plate solar hybrid system for heating and cooling. They reported that this new hybrid machine will be of high efficiency of solar energy conversion, and a good choice for the utilization of solar energy with solar irradiance intensity of $18-22 \mathrm{MJ} / \mathrm{m}^{2}$ (5-6.1 $\mathrm{kWh}$ /day).Kalogirou (2003) mentioned that flat plate collectors are usually permanently fixed in position and require no tracking of the sun. The collectors should be oriented directly towards the equator, facing south in the northern hemisphere and north in the southern. The optimum tilt angle of the collector is equal to the latitude of the location with angle variations of $10-15^{\circ}$ more or less depending on the application. Abdellatif et al. (2006a,b) compared two similar solar water heaters of flat plate type under clear sky conditions to investigate the effect of orientation and tilt angles, and water inlet temperature on the thermal performance. They revealed that, the solar water heater which was oriented and tilted to track the sun's rays once each half hour from sunrise to sunset was an average $20.98 \%$ more efficient than a startionary non-tracking solar heater. The obtained results also showed that, the water inlet temperature was directly proportional to the solar energy system heat losses and consequently it was inversely proportional to the overall thermal efficiency. As the water inlet temperature increased; firstly, the operating temperature of the absorber plate increased above the ambient air temperature surrounding the solar panel and thus heat losses increased; secondly, the difference in temperature 
between the absorber plate and the water reduced, making the heat transfer less efficient. For these reasons the daily average heat transfer efficiencies for the two solar panels using two different water inlet temperatures $\left(29.5\right.$ and $18.8^{\circ} \mathrm{C}$ ) were $81.12 \%$ and $91.47 \%$, consequently $18.88 \%$ and $8.53 \%$ of the absorbed solar energy were lost, respectively. Sozen et al. (2008) used the flat-plate solar collectors to heat water by circulating fluid to a temperature considerably less than that of the boiling point of water and are best suited to applications where the required temperature is $30-70^{\circ} \mathrm{C}$. Integral closed circuit (pressurized) stainless steel storage tank with natural thermo-siphon system. A closed circuit solar water heater system is a system where the storage tanks' water is circulated directly from the storage tank through the solar collector. They also indicated that calculation of performance of the solar thermal collector is very complex and based on different working angles and parameters. These angles such as: altitude, azimuth, solar declination, incidence and collector tilt angles. Also, they added that the efficiency of flat-plate solar collector depends on many parameters including mean ambient temperature, date, time and solar radiation.Nuntaphan et al. (2009) used a collector area about $4 \mathrm{~m}^{2}$ and volume of water in the storage tank ranged between 100 and 300 Liter with the mass flow rate between 6 and $121 / \mathrm{min}$. They found that a single solar collector can produce approximately $48-56^{\circ} \mathrm{C}$ hot water with an average solar radiation of $600-700 \mathrm{~W} / \mathrm{m}^{2}$ at a mass flow rate of $0.2 \mathrm{~kg} / \mathrm{s}$. Their results further showed that the higher water volume exhibited the lower water temperature and the mass flow rate of water had no effect on the water temperature under these conditions. From the previous litterature, there are many factors affecting outlet fluid temperature. Therefore, the objectives of this research are to:

1- Study the factors which affect the outlet fluid temperature such as: solar radiation, water flow rate, water inlet temperature, ambient air temperature and absorber plate temperature.

2- Determine the mathematical relationships between these parametersu using SAS static programme. 


\section{MATERIALS AND METHODS}

The solar energy system was designed and constructed in a private workshop, and installed on the roof of house at Denosher village, ElMehalla El-Kobra, El-Ghrabia Governorate (latitude angle of $30.9^{\circ} \mathrm{N}$ ) as shown in Fig.(1). The experiments were carried outf from $15^{\text {th }}$ August until $25^{\text {th }}$ September 2010. The solar energy system include a solar collector, an insulated heat storage tank, a heat exchanger, a fluid distribution system and a control system. The solar collector consisted of five components (collector box, absorber plate, copper pipes, insulation material, and glass cover), as mentioned by Darwesh (2010). Three different volumes of water (40, 150 and 240 liters) and three different mass flow rates $(0.033,0.125$ and $0.200 \mathrm{~kg} / \mathrm{s})$ were used during the experimental period. This volumes depended upon the number of circulation rate per hour through solar collector according the following equation balance:

$$
\frac{\left(\dot{m}_{1} \times t\right)}{m_{1}}=\frac{\left(\dot{m}_{2} \times t\right)}{m_{2}}=\frac{\left(\dot{m}_{3} \times t\right)}{m_{3}}=N
$$

Where:-

$$
\dot{m}=\begin{aligned}
& \text { mass flow rate } \\
& \text { operating fluid }
\end{aligned}
$$

$\mathrm{t}=$ time $(\mathrm{s})$

$m=$ mass of water in the storage tank $\left(m_{1}=40, m_{2}=150, m_{3}=240\right.$ liters) $\mathrm{N}=$ the mass unit of water which circulates in the solar collector, dimensionless

\section{Instrumentation}

1. Temperature: two data loggers each having eight channels were used to meausre different temperatures. Each data logger has a keyboard, a monitor, a programmed card and controllers. The two data-loggers were connected with fourteen sensors (therimstors type) to measure the temperature at selected positions in the solar energy system as demonstrated in Fig.(2). The data were updated by a scan of all the sensors every to second, and the mean of 600 scans was reached each on a computer. 
2.Solar radiation: A pyranometer, Kipp and Zohne, Holand was used to measure the solar radiation flux incident on a horizontal surface. The device has an output of approximately $0.5 \mathrm{mV}$ per $100 \mathrm{~W} / \mathrm{m}^{2}$. The expected solar radiation was in the range of $0-1100 \mathrm{~W} / \mathrm{m}^{2}$. The solarimeter was connected to a voltammeter device to measure the solar radiation flux incident on any surface in $\mathrm{W} / \mathrm{m}^{2}$, as illustrated in Fig. (3).

The experiments were carried out to study the effect of some operating parameters on the water outlet temperature of the solar collector. Four sunny days were selected for each flow rate. Each experimental day started from 9 am till $4 \mathrm{pm}$.

\section{Temperature Measurements}

The temperatures at different locations of solar energy systems were measured and recorded as shown in Figs. (1 and 4). These measurements include: glass cover, absorber plate, outlet, inlet of water and storage tank. Some points took three sensors according to the nature and importance of this part. Three sensors were used to the absorber plate temperature, and the average of three temperatures was taken in the calculations.

\section{Solar collector measurements:}

To measure factors which affecting outlet water temperature should be calculated some values as following:

- Avilable solar energy (Q): which could be calculated as a function of solar radiation flux incident $(\mathrm{R})$ and solar heater surface area $\left(\mathrm{A}_{\mathrm{C}}\right)$ as follows:

$$
Q=R A_{C}, \mathrm{~W} \text {. }
$$

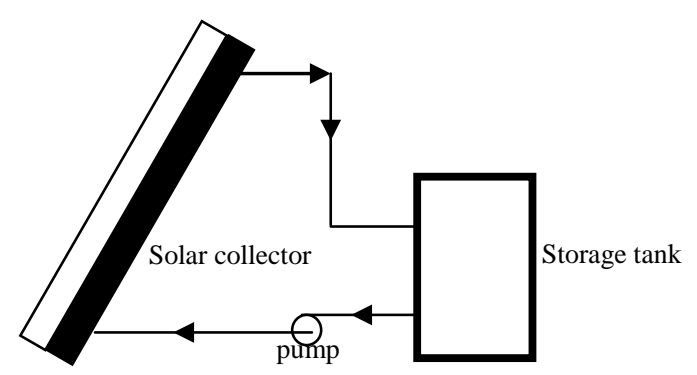

Fig. (1): Schematic diagram of the solar energy system using the forced how system 
PROCESS ENGINEERING

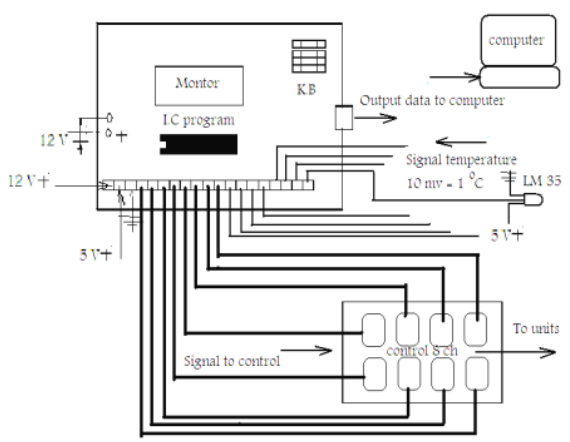

Fig.(2):Schematic diagram of each data logger with the computer.

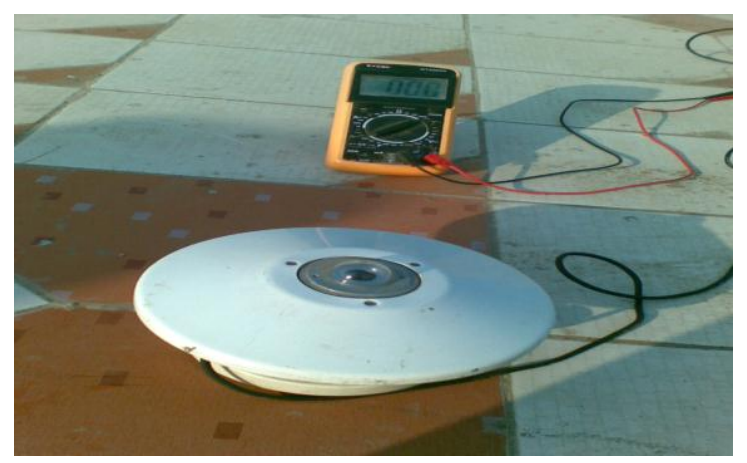

Fig. (3): The pyranometer device and digital voltammeter used to measure the solar radiation flux incident.

Outlet temperatures of the solar collector.

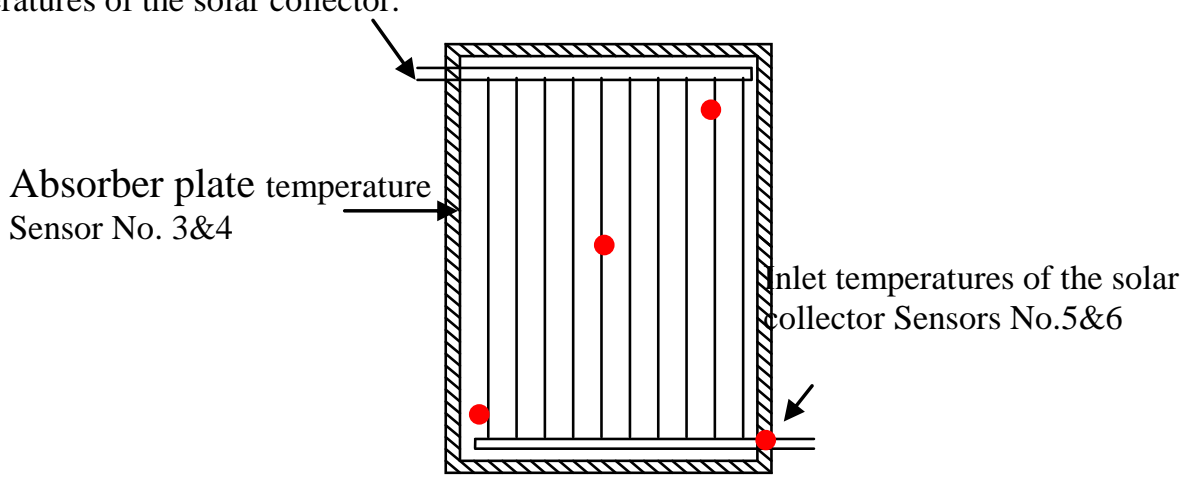

Fig. (4): Distribution of sensors on the solar collectors. 
The useful heat gain $\left(\mathrm{Q}_{\mathrm{C}}\right)$ : which represents the rate of extraction of heat from the collector may be measured by means of the amount of heat carried away in fluid passed through it, as follows

$$
\mathrm{Q}_{\mathrm{C}}=\mathrm{mC}_{\mathrm{P}}\left(\mathrm{T}_{\mathrm{fo}}-\mathrm{T}_{\mathrm{fi}}\right), \mathrm{W} \text {. }
$$

Where:

$$
\begin{array}{rlrl}
\mathrm{m} & =\text { mass flow rate of fluid, } & & \mathrm{kg} / \mathrm{s} \\
\mathrm{C}_{\mathrm{P}} & =\text { specific heat of fluid, } & & \mathrm{J} / \mathrm{kg} /{ }^{\circ} \mathrm{C} \\
\mathrm{T}_{\mathrm{fo}}=\text { outlet temperature of fluid, }, & { }^{\circ} \mathrm{C} \\
\mathrm{T}_{\mathrm{fi}}=\text { inlet temperature of fluid, } & & { }^{\circ} \mathrm{C}
\end{array}
$$

Overall thermal efficiency $\left(\eta_{\mathrm{o}}\right)$ : which defined as the ratio of the useful energy gain $\left(\mathrm{Q}_{\mathrm{C}}\right)$ to the incident solar energy over a particular time period as follows:

$$
\eta_{o}=\frac{Q_{C}}{Q} \times 100
$$

Temperature rise $\left(\mathrm{D}_{\mathrm{T}}\right)$ : which equal the different between fluid inlet temperature $\left(\mathrm{T}_{\mathrm{fi}}\right)$ and the ambient air temperature $\left(\mathrm{T}_{\mathrm{a}}\right)$ divided by solar energy flux incident, can be determined from the following equation:

$$
\mathrm{D}_{\mathrm{T}}=\frac{\left(T_{f i}-T_{a}\right)}{R} \quad, \quad \mathrm{~m}^{2} \cdot{ }^{\circ} \mathrm{C} / \mathrm{W} .
$$

\section{Statistical analysis:}

The recorded data were statistically analyzed using the SAS statistical Package Version 8.2 with the procedure of regression. The Forward, backward and mixed multiple regression models were applied to determine the best model for demonstrating the relationship between the outlet water temperature as a function of the solar radiation flux incident on the absorber plate, inlet water and ambient air temperatures.

\section{RESULTS AND DISCUSSION}

The mean values for the four days were calculated for different mass flow rates to investigate the relationship between all variables studied in this resarch. The obtained data are listed and summerized in Table (1) and depicted in Figs.5, 6,7 and 8 for the three different mass flow rates, respectively. The results of the regression analysis are shown Fig.9 . 
Table (1). Hourly average solar radiation flux incident (R), absorber plat $\left(T_{P}\right)$, ambient air $\left(T_{a}\right)$, inlet water $\left(T_{f i}\right)$, outlet water $\left(T_{f o}\right)$ temperatures, difference between outlet and inlet water temperatures (dT) for the three different mass flow rates, normalized temperature rise $\left(\mathrm{D}_{\mathrm{T}}\right)$ and overall thermal efficiency, $\left(\eta_{\mathrm{o}}\right) \cdot \mathrm{m}^{2} .{ }^{\circ} \mathrm{C} / \mathrm{W}$

\begin{tabular}{|c|c|c|c|c|c|c|c|c|}
\hline Time & $\mathrm{R}, \mathrm{W} / \mathrm{m}^{2}$ & $\mathrm{~T}_{\mathrm{P}},{ }^{\circ} \mathrm{C}$ & $\mathrm{Ta},{ }^{\circ} \mathrm{C}$ & $\mathrm{T}_{\mathrm{fi}},{ }^{\circ} \mathrm{C}$ & $\mathrm{T}_{\mathrm{fo}},{ }^{\circ} \mathrm{C}$ & $\mathrm{dT},{ }^{\circ} \mathrm{C}$ & $\mathrm{DT}, \mathrm{m}^{2} \cdot{ }^{\circ} \mathrm{C} / \mathrm{W} \times 10^{-2}$ & $\eta_{\mathrm{o}}, \%$ \\
\hline \multicolumn{9}{|c|}{ Mass flow rate, $0.033 \mathrm{~kg} / \mathrm{s}$} \\
\hline 9 & 657.0 & 68.0 & 29.9 & 50.0 & 55.9 & 5.9 & 3.059361 & 70.55 \\
\hline 10 & 785.5 & 77.1 & 32.5 & 55.9 & 62.2 & 6.3 & 2.978994 & 70.09 \\
\hline 11 & 896.8 & 86.3 & 33.8 & 62.1 & 70.7 & 8.6 & 3.155665 & 71.04 \\
\hline 12 & 893.3 & 94.0 & 34.9 & 70.7 & 79.1 & 8.4 & 4.007612 & 70.25 \\
\hline 13 & 841.6 & 101.8 & 32.7 & 79.0 & 87.2 & 8.3 & 5.501426 & 68.82 \\
\hline 14 & 723.4 & 108.6 & 33.1 & 87.2 & 94.9 & 7.7 & 7.478573 & 63.60 \\
\hline 15 & 512.4 & 110.3 & 31.8 & 94.9 & 100.5 & 5.6 & 12.3146 & 55.90 \\
\hline 16 & 337.0 & 107.8 & 27.4 & 100.5 & 103.2 & 2.7 & 21.69139 & 41.84 \\
\hline \multicolumn{9}{|c|}{ Mass flow rate, $0.125 \mathrm{~kg} / \mathrm{s}$} \\
\hline 9 & 662.0 & 65.3 & 24.9 & 50.0 & 51.4 & 1.4 & 3.791541 & 62.86 \\
\hline 10 & 797.8 & 69.8 & 26.5 & 51.4 & 53.3 & 1.9 & 3.121083 & 65.14 \\
\hline 11 & 969.7 & 75.8 & 26.0 & 53.2 & 55.6 & 2.4 & 2.804991 & 66.23 \\
\hline 12 & 995.7 & 77.9 & 25.9 & 55.5 & 58.0 & 2.4 & 2.972783 & 66.43 \\
\hline 13 & 896.8 & 78.5 & 24.9 & 57.9 & 60.1 & 2.2 & 3.67975 & 63.38 \\
\hline 14 & 747.9 & 77.3 & 24.3 & 60.1 & 61.9 & 1.9 & 4.786636 & 63.72 \\
\hline 15 & 504.8 & 73.4 & 22.6 & 61.9 & 63.0 & 1.1 & 7.785261 & 49.03 \\
\hline 16 & 347.7 & 69.1 & 21.2 & 62.9 & 63.3 & 0.4 & 11.9931 & 32.32 \\
\hline \multicolumn{9}{|c|}{ Mass flow rate, $0.200 \mathrm{~kg} / \mathrm{s}$} \\
\hline 9 & 628.4 & 64.0 & 26.3 & 50.0 & 51.1 & 1.1 & 3.771483 & 86.88 \\
\hline 10 & 762.8 & 68.1 & 27.7 & 51.0 & 52.3 & 1.3 & 3.054536 & 90.08 \\
\hline 11 & 908.1 & 73.7 & 27.5 & 52.3 & 53.9 & 1.6 & 2.730977 & 92.41 \\
\hline 12 & 924.8 & 75.6 & 26.8 & 53.9 & 55.5 & 1.6 & 2.930363 & 91.00 \\
\hline 13 & 836.3 & 74.9 & 27.4 & 55.4 & 56.9 & 1.5 & 3.348081 & 90.25 \\
\hline 14 & 660.3 & 71.6 & 27.4 & 56.9 & 58.0 & 1.2 & 4.467666 & 79.97 \\
\hline 15 & 505.3 & 69.9 & 26.2 & 58.0 & 58.9 & 0.9 & 6.293291 & 67.39 \\
\hline 16 & 299.3 & 65.3 & 23.3 & 58.8 & 59.3 & 0.5 & 11.86101 & 44.24 \\
\hline
\end{tabular}




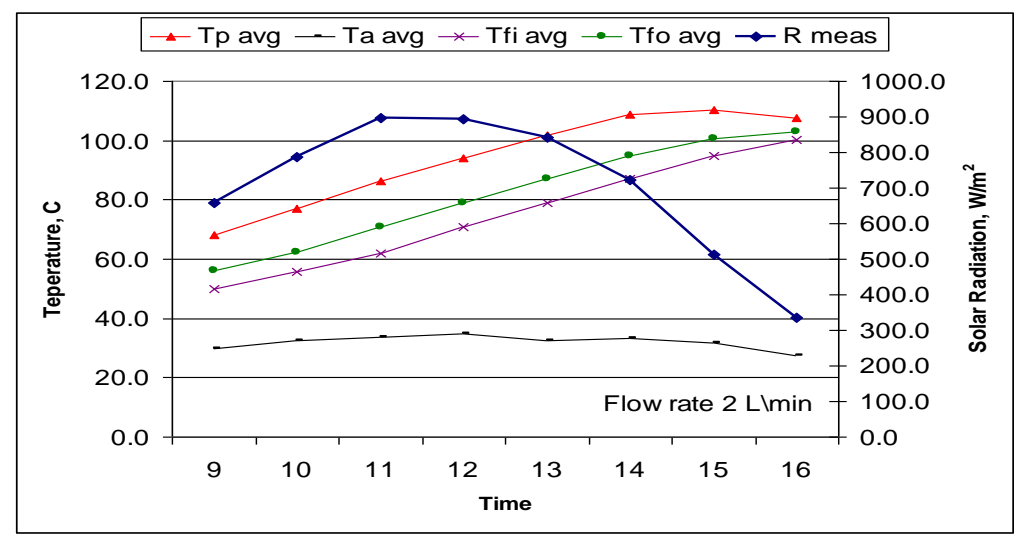

Fig.(5): Hourly average temperatures and solar radiation incident for the mass flow rate $0.033 \mathrm{~kg} / \mathrm{s}$ throughout the day.

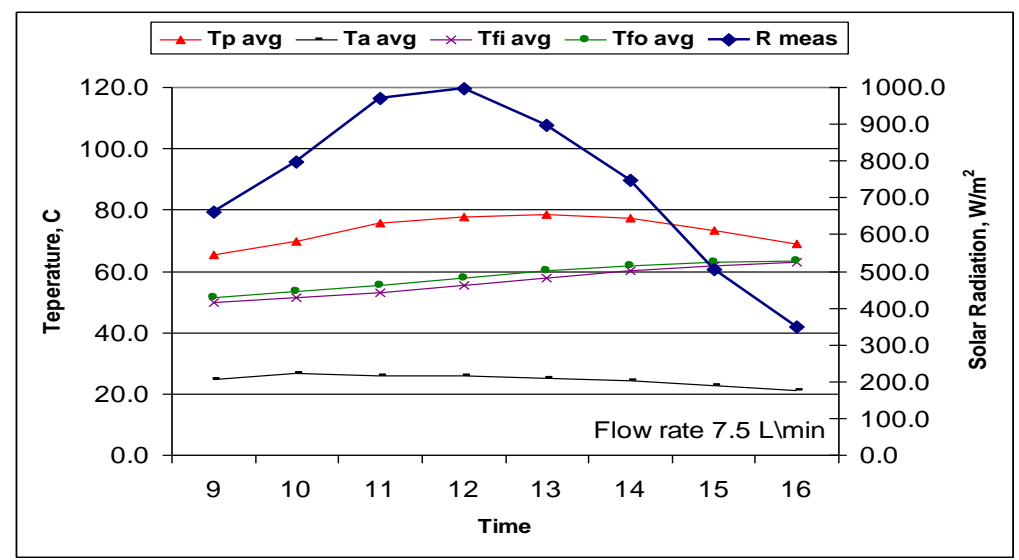

Fig.(6): Hourly average temperatures and solar radiation incident for the mass flow rate $0.125 \mathrm{~kg} / \mathrm{s}$ throughout the day.

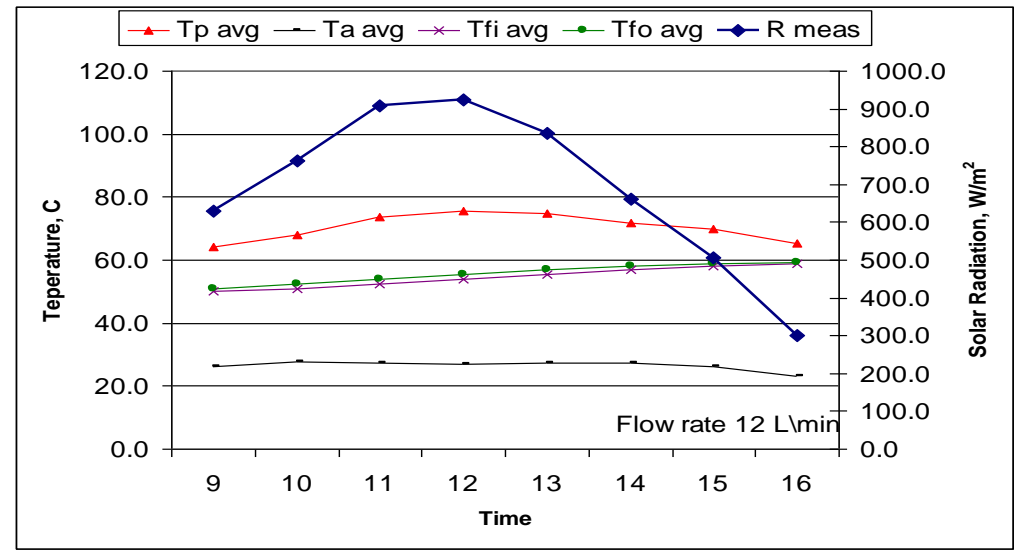

Fig.(7): Hourly average temperatures and solar radiation incident for the mass flow rate $0.200 \mathrm{~kg} / \mathrm{s}$ throughout the day. 


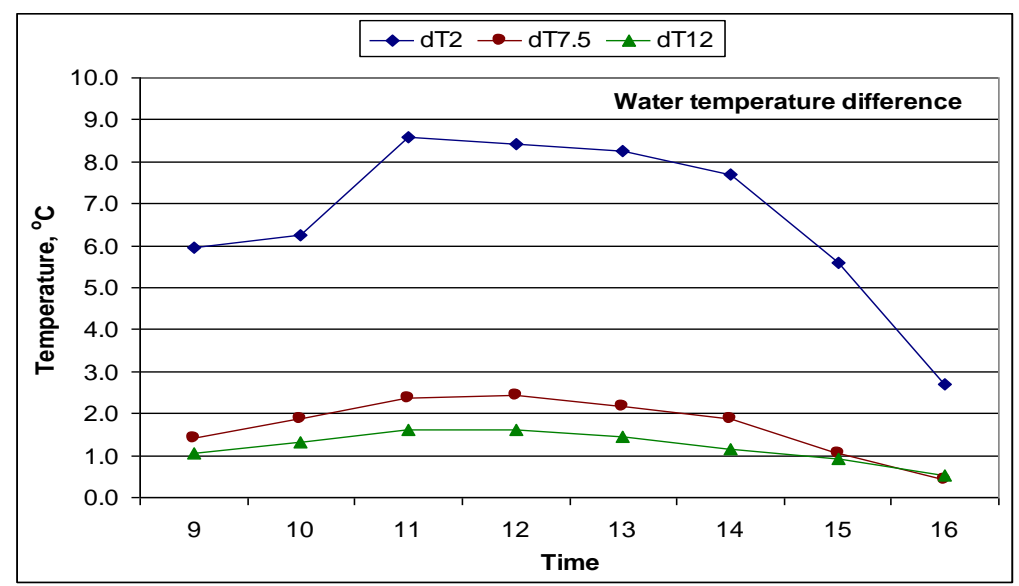

Fig.(8): The average temperature differences between the water outlet and inlet temperature for three flow rates throughout the day.

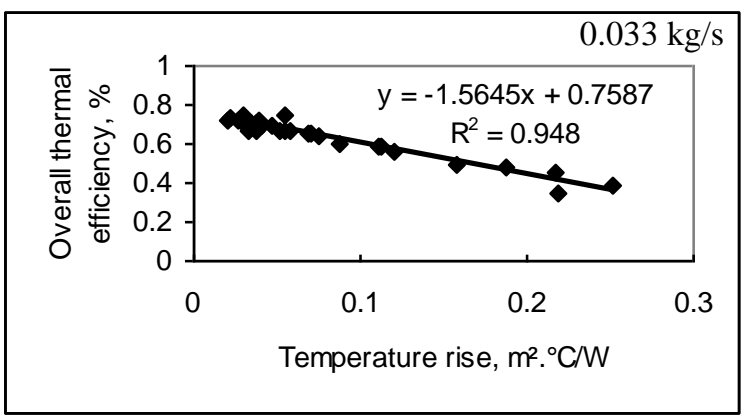

a

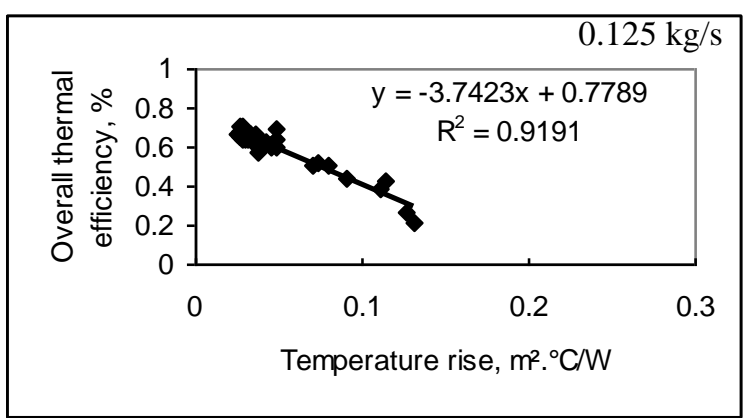

b

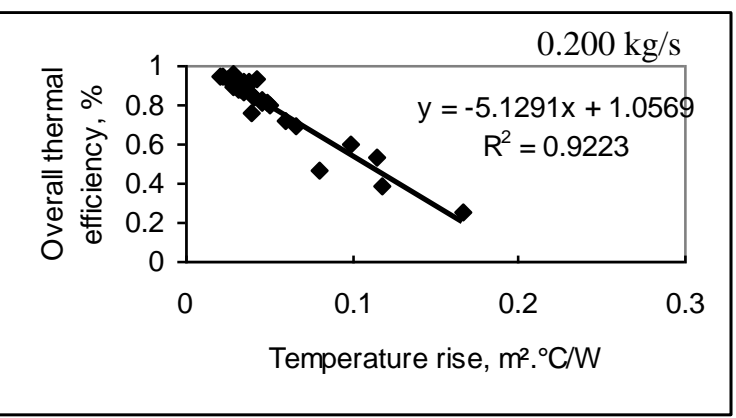

c

Fig. (9 a, b, c): Overall thermal efficiency against temperature rise for different mass flow rates. 
The hourly average solar radiation shown in Fig. (5) and Table (1) for the mass flow rate of $0.033 \mathrm{~kg} / \mathrm{s}$ was $657 \mathrm{~W} / \mathrm{m}^{2}$, and increased gradually until reached $893.3 \mathrm{~W} / \mathrm{m}^{2}$ at noon. Then it declined till reached 337 $\mathrm{W} / \mathrm{m}^{2}$ at $4 \mathrm{pm}$. While, the absorber plat temperature at 9 am was $68{ }^{\circ} \mathrm{C}$ and gradually increased until reached its maximum temperature (110.3 $\left.{ }^{\circ} \mathrm{C}\right)$ at $3 \mathrm{pm}$ then decreased. The outlet water temperature at 9 am was $55.9{ }^{\circ} \mathrm{C}$, and staidly increased till the end of the daylight $\left(109.3{ }^{\circ} \mathrm{C}\right)$.It was observed that, the outlet water temperature almost in parallel with the inlet water temperature.

The data depicted in Fig. (6) and listed in Table (1) for the mass flow rate of $0.125 \mathrm{~kg} / \mathrm{s}$ revealed that the hourly average solar radiation incident was $660 \mathrm{~W} / \mathrm{m}^{2}$, and increased gradually until reached $896.8 \mathrm{~W} / \mathrm{m}^{2}$ at noon. Then it decline till reached $347.7 \mathrm{~W} / \mathrm{m}^{2}$ at $4 \mathrm{pm}$. While, The absorber plat temperature at 9 am was $65.3{ }^{\circ} \mathrm{C}$ and increased gradually until reached its maximum temperature $78.5{ }^{\circ} \mathrm{C}$ at noon then decreased. The outlet water temperature at 9 am was $51.4{ }^{\circ} \mathrm{C}$ and staidly increased till the end of the day-light $63.3^{\circ} \mathrm{C}$.

The data for the mass flow rate of $0.200 \mathrm{~kg} / \mathrm{s}$ are presented in Table (1) and Fig. (7). It is clear that the average solar radiation incident increased from 628.2 to $924.8 \mathrm{~W} / \mathrm{m}^{2}$ at noon then decreased throughout the rest of the day. However, the absorber plate temperature raised from 64 to 75.7 ${ }^{\circ} \mathrm{C}$ also at noon then decreased untill the end of the day. While, the water outlet temperature increased gradually from 51.1 to $59.3{ }^{\circ} \mathrm{C}$ at the end of the day.

It is obviously showed that the mass flow rate of $0.200 \mathrm{~kg} / \mathrm{s}$ gained the most of the solar radiation flux incident on the absorber plate, than that of the other flow rates. The difference between outlet and inlet water temperature is shown in Table (1) and Figure (8). It was observed that increasing the flow rate led to minimize the difference between outlet and inlet water temperature.

The overall efficiency of the solar collector is a combination of absorption and heat transfer efficiencies. For the duration of the experimental work, the daily average overall thermal efficiency for 15 August and 25 September 2010 for $0.033,0.125$ and $0.200 \mathrm{~kg} / \mathrm{s}$ was $64.01,58.63$ and $80.27 \%$, respectively. The overall thermal efficiency of 
the solar collector $\left(\eta_{\mathrm{o}}\right)$ was plotted as a function of the temperature rise $\mathrm{D}_{\mathrm{T}}$ to examine their relationships with different mass flow rates as shown in (Fig.9). The overall thermal performance of the solar collector can be represented as:-

$$
\begin{aligned}
& \eta_{\mathrm{o}}=\mathrm{F}_{\mathrm{R}}(\tau \alpha)-\mathrm{U}_{\mathrm{o}} \mathrm{F}_{\mathrm{R}}\left[\frac{T_{f i}-T_{f o}}{R}\right] \ldots \ldots \\
& \eta_{\mathrm{o}}=\mathrm{F}_{\mathrm{R}}(\tau \alpha)-\mathrm{U}_{\mathrm{o}} \mathrm{F}_{\mathrm{R}}\left(\mathrm{D}_{\mathrm{T}}\right) \ldots \ldots \ldots \ldots \ldots \ldots \ldots \ldots \ldots \ldots \ldots \ldots \ldots \ldots \ldots \ldots \ldots \ldots \ldots
\end{aligned}
$$

Equation (6) is certainly the numerical representation of equations (9), (10) and (11). The y-intercept (a) is represent and equal to the product of the heat removal factor $\left(F_{R}\right)$, transmittance of the glass cover $(\tau)$, and absorptance of the absorber black plate $(\alpha)$. The slope (b) is symbolize and equal the product of the heat removal factor and overall heat transfer coefficient $\left(\mathrm{U}_{\mathrm{o}}\right)$. The plot of overall thermal efficiency against temperature rise during the experimental work was straight line with $y$ intercept $F_{R}(\tau \alpha)$ and slope $\left(-F_{R} U_{o}\right)$. The regression analysis also clarified that the highest $\mathrm{R}^{2}$ was recorded with $0.033 \mathrm{~kg} / \mathrm{s}$ mass flow rate but the overall thermal efficiency was low. This may have been a result of the higher outlet water temperature with this treatment.

Regression analysis revealed a high significant linear relationship between temperature rise and overall thermal efficiency atdifferent mass flow rates as follows:-

$$
\begin{aligned}
& \eta_{\mathrm{o}}=0.7587-1.5645 \mathrm{X} \text { at } \quad \dot{m}_{1}=0.033 \mathrm{~kg} / \mathrm{s} . \\
& \eta_{\mathrm{o}}=0.7789-3.7423 \mathrm{X} \text { at } \quad \dot{m}_{2}=0.125 \mathrm{~kg} / \mathrm{s} . \\
& \eta_{\mathrm{o}}=1.0569-5.1291 \mathrm{X} \text { at } \quad \dot{m}_{3}=0.200 \mathrm{~kg} / \mathrm{s} .
\end{aligned}
$$

The multiple regression analysis for the data (forward, backward and mixed regression analysis was performed to drive a relationship between the outlet water temperature and the other measured factors; solar radiation incident, absorber plate, ambient air and inlet water temperatures for the three flow rates. The output result of the forward regression analysis pointed out by evaluating the data by its effect on the model, it firstly got out the best 1-variable model with entering the inlet water temperature and the corresponding $\mathrm{R}^{2}$ value was 0.974 with single liner regression equation: 
$\mathrm{T}_{\mathrm{fo}}=1.0899 \mathrm{~T}_{\mathrm{fi}}-2.38356$.

The best 2-variable model when the absorber plate temperature entered to the previous one. The $\mathrm{R}^{2}$ was 0.986 with the multiple regression equation:

$$
\mathrm{Tfo}=0.819 \mathrm{~T}_{\mathrm{fi}}+0.288 \mathrm{~T}_{\mathrm{p}}-8.455
$$

The best 3-variable model was achieved when the ambient air temperature entered the model. It increased the coefficient of determination $\mathrm{R}^{2}$ to value of 0.9898 . The regression equation was:

$$
\mathrm{T}_{\mathrm{fo}}=0.884 \mathrm{~T}_{\mathrm{fi}}+0.192 \mathrm{~T}_{\mathrm{p}}+0.2505 \mathrm{~T}_{\mathrm{a}}-11.76 \text {. }
$$

The analysis revealed that when the all variables were entered in the model, the coefficient of determionation $\left(\mathrm{R}^{2}\right)$ was 0.9902 with a regression equation of:

$$
\text { Tfo }=-0.0035 \mathrm{R}+0.2989 \mathrm{~T}_{\mathrm{p}}+0.443 \mathrm{~T}_{\mathrm{a}}+0.767 \mathrm{~T}_{\mathrm{fi}}-10.316 \ldots . .(15)
$$

The multiple regression analysis showed the all possible combination could be taken from all variable and are showed in Table (2).

Table (2): The multiple regression analysis for all possible combination taken from all varaibles

\begin{tabular}{|c|c|c|}
\hline No. of variable in Model & R-Square & Variables in Model \\
\hline 1 & 0.9743 & $\mathrm{~T}_{\mathrm{fi}}$ \\
\hline 1 & 0.8957 & $\mathrm{~T}_{\mathrm{p}}$ \\
\hline 1 & 0.1692 & $\mathrm{~T}_{\mathrm{a}}$ \\
\hline 1 & 0.0645 & $\mathrm{R}$ \\
\hline 2 & 0.9861 & $\mathrm{~T}_{\mathrm{p}}, \mathrm{T}_{\mathrm{fi}}$ \\
\hline 2 & 0.9860 & $\mathrm{~T}_{\mathrm{a}}, \mathrm{T}_{\mathrm{fi}}$ \\
\hline 2 & 0.9821 & $\mathrm{R}, \mathrm{T}_{\mathrm{fi}}$ \\
\hline 2 & 0.9770 & $\mathrm{R}, \mathrm{T}_{\mathrm{p}}$ \\
\hline 2 & 0.8985 & $\mathrm{~T}_{\mathrm{p}}, \mathrm{T}_{\mathrm{a}}$ \\
\hline 2 & 0.3173 & $\mathrm{R}, \mathrm{T}_{\mathrm{a}}$ \\
\hline 3 & 0.9898 & $\mathrm{~T}_{\mathrm{p}}, \mathrm{T}_{\mathrm{a}}, \mathrm{T}_{\mathrm{fi}}$ \\
\hline 3 & 0.9881 & $\mathrm{R}, \mathrm{T}_{\mathrm{a}}, \mathrm{T}_{\mathrm{fi}}$ \\
\hline 3 & 0.9867 & $\mathrm{R}, \mathrm{T}_{\mathrm{p}}, \mathrm{T}_{\mathrm{fi}}$ \\
\hline 3 & 0.9782 & $\mathrm{R}, \mathrm{T}_{\mathrm{p}}, \mathrm{T}_{\mathrm{a}}$ \\
\hline 4 & 0.9902 & $\mathrm{R}, \mathrm{T}_{\mathrm{p}}, \mathrm{T}_{\mathrm{a}}, \mathrm{T}_{\mathrm{fi}}$ \\
\hline
\end{tabular}


PROCESS ENGINEERING

\section{CONCLUSION}

The obtained data of this experimental work can be summarized and concluded as follows:

1- The $0.033 \mathrm{~kg} / \mathrm{s}$ mass flow rate produced the highest outlet water temperature $103.2{ }^{\circ} \mathrm{C}$, while 0.125 and $0.200 \mathrm{~kg} / \mathrm{s}$ produced 63.3 and $59.3{ }^{\circ} \mathrm{C}$, respectively.

2- The results of the regression analysis indicated that, under the experimental conditions, it is possible predict the outlet water temperature by measuring both the inlet and the absorber plate temperatures.

\section{REFERENCES}

Abdellatif, S. M (1985). Solar energy collection, storage and utilization in protected cropping. Ph.D Thesis, Wye College, University of London, UK.

Abdellatif, S. M.; A. M. Matouk and R. E. Matouk (2006a). Effect of mass flow rate of operating fluid on solar panel thermal performance. J. Agric. Sci. Mansoura University, 31(7):479-496.

Abdellatif, S. M.; A. M. Matouk and R. E. Matouk (2006b). Effect of orientation, tilt angles and water inlet temperature on solar panel thermal performance. J. Agric. Sci., Mansoura University, 31(7): 497-510.

Abdellatif, S.M.; S.A. Hamada; M.A. Hemeda; and M.A. abdelal (1990). Operating and environmental parameters affecting thermal performance of flat plate collectors. Misr, J. Ag. Eng., 7(4): 384401.

Darwesh, M.R.A (2010). Utilization of solar absorption refrigeration system for potato crop storage. Ph.D. Thesis, Agric. Mech. Dept., Fac. of Agric., Tanta Univ, Egypt.

Fanney, H.A.; and S.A. Klein (1988). Thermal performance comparisons for solar hot water systems subjected to various collector and heat exchanger flow rates. Solar Energy, 40(1): 1-11.

George, H.A.; L.F. Donald; and K. Gary (1980). Solar collector design-high temperature. ASAE Paper No. 80-4036. 
Jesch, L.F.; and J.E. Braun (1984). Variable volume storage and stratified storage for improved water heater performance. Solar Energy, 33(1) : 83-87.

Kalogirou, S. (2003). The potential of solar industrial process heat applications. Applied Energy, 76 (4): 337-361.

Li, M., and R. Wang, (2002). A study of the effects of collector and environment parameters on the performance of a solar powered solid adsorption refrigerator. Renewable energy, $27: 369-382$.

Meinel, A. B. and M. P. Meinel. (1979). Applied Solar Energy: An Introduction. Addison-Wesley Publishing Company, Inc. $4^{\text {th }}$ printing.

Nuntaphan, A.; C. Chansena and T. Kiatsiriroat (2009). Performance analysis of solar water heater combined with heat pump using refrigerant mixture. Applied Energy, 86: 748-756.

Sozen, A.; T. Menlik and Unvar, S. (2008). Determination of efficiency of flat-plate solar collectors using neural network approach. Expert Systems with Applications, 35 (4): 1533-1539.

Vandeplas, P.; and P. Dirven (1990). A new developed high efficiency solar collector and related heat transfer system. Acta Horticultural, 263: 379-382.

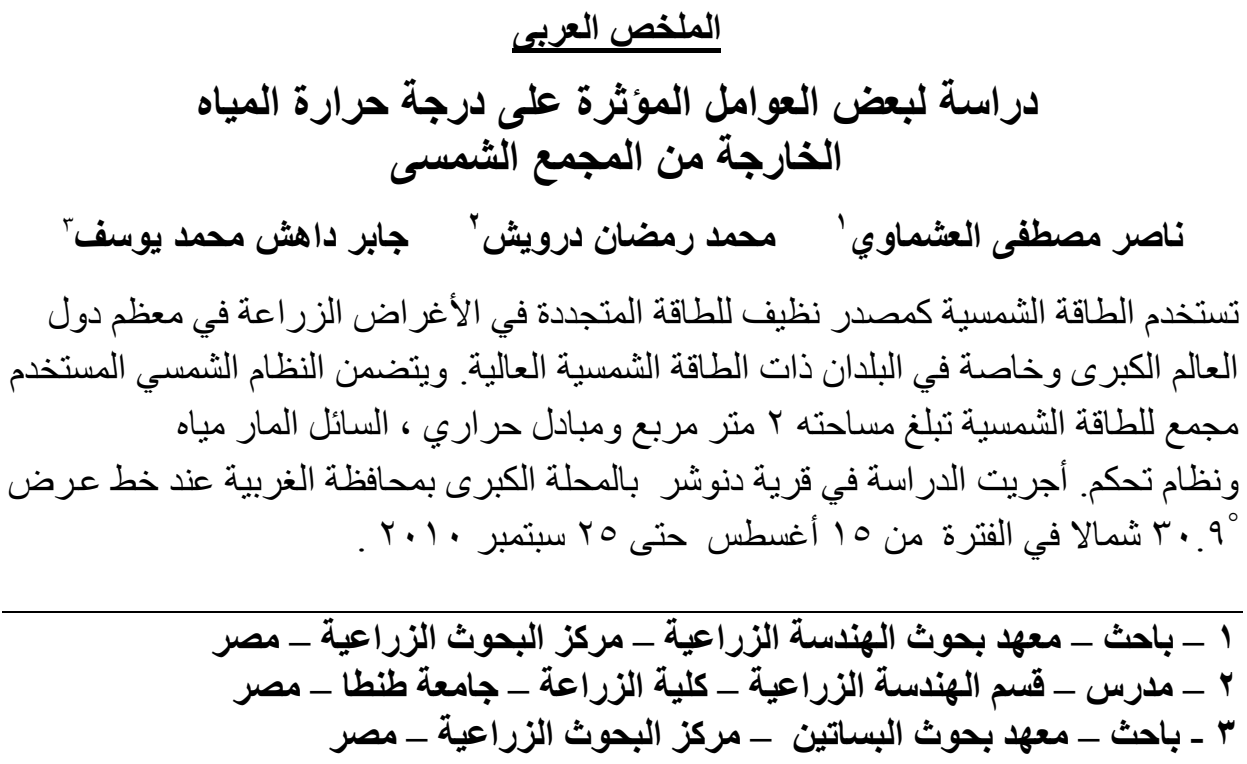




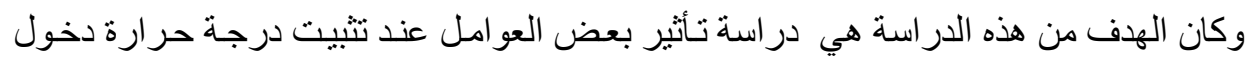

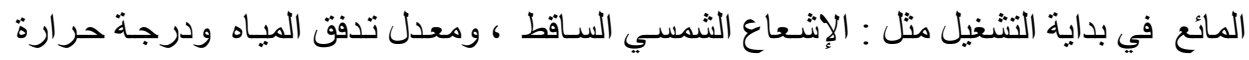

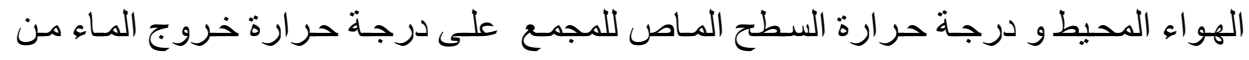
المجمع .

حيث تم تثبيت درجة حر ارة دخول المياه عند درجة حر ارة تدفق هي :- $0.033,0.125$ and $0.200 \mathrm{~kg} / \mathrm{s}$ وكانت أهم النتائج المتحصل عليها هي:-

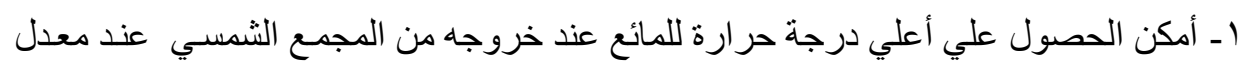

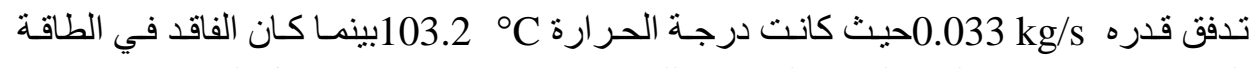

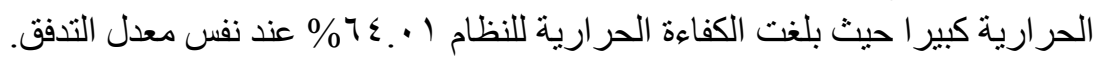

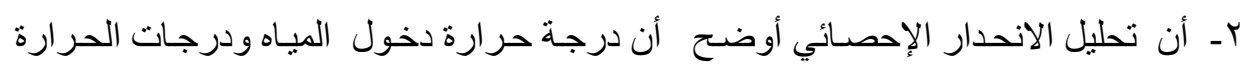

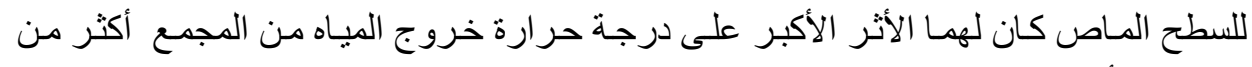
العو امل الأخرى. وكانت المعادلة المتحصل عليها لإكيا هي:-

Tfo $=-0.0035 R+0.2989 T_{p}+0.443 T_{a}+0.767 T_{f i}-10.316$ 